\title{
Complete Response Case of an In-operable Gallbladder Carcinoma Treated with Chemo-hyperthermia, Radiotherapy and Hyperbaric Oxygen Therapy
}

\author{
YOSHINORI TOMODA, SHIN OHTA, HAJIME IMADA*, \\ HIROYUKI NARISADA, TOMOAKI MORIOKA
}

Tobata Kyoritsu Hospital, Cancer treatment center, 2-5-1, Sawami, Tobata-ku, Kitakyushu-city, Fukuoka 804-0093, Japan

\begin{abstract}
A 60s woman with an in-operable stage IVA (T4N0M0) gallbladder carcinoma invaded to liver, duodenum and transverse colon visited our hospital in May 200X. 61.2 Gy of Radiotherapy, chemotherapy (weekly gemcitabine), hyperthermia and hyperbaric oxygen therapy (HBO) was performed for abdominal tumor. After chemo-radiotherapy, maintenance biweekly chemo-hyperthermia and HBO was performed for a year. Clinical complete response was obtained at April $200 \mathrm{X}+1$. After that, she ingested S-1 for 18 months. She survives with no evidence of disease for 6 years and 9 months after treatment. Late adverse event was only grade 2 radiation duodenitis controlled with medical treatment.

Chemo-radiotherapy combined with hyperthermia and HBO for locally advanced gallbladder carcinoma could contribute to a better clinical outcome and it was suggested that these treatment was very useful.
\end{abstract}

Key Words : gallbladder carcinoma, chemo-hyperthermia, radiotherapy, hyperbaric oxygen therapy

はじめに

胆囊癌は予後が不良な疾患であり，外科的切除が唯一の根治治療であるが，切除不能な進行胆囊癌に ついては未だに標準的な治療法が確立されていない。これまで進行胆囊癌に対する集学的治療について の報告が複数認められ，三者併用療法 (温熱・化学・放射線療法) は化学療法ないし放射線療法単独より も平均生存期間が有意に延長するということが報告されている ${ }^{11}$. 今回我々の施設において, 治癒切除 不能として紹介され温熱療法を加えた集学的治療にて完全奏効と判断された進行胆囊癌の症例を経験し たので，報告する．

症例

患者：60歳代 女性. 主訴：特になし. 既往歴：特記事項なし. 家族歴：特記事項なし. 生活歷： 喫煙歴なし, 飲酒歴なし. 現病歴： $200 X$ 年 2 月より右季肋部痛あり, 近医腹部エコー検査にて胆囊壁 の肥厚を認めた．前医の造影 CT で，肝床部への直接浸潤を伴う進行胆囊癌の診断であり，4月に手術

Received 8 May, 2015, Accepted 7 September, 2016. *Corresponding author: Tel, +81-93-871-5421; Fax, +81-93-871-5499;

e-mail,himada60@gmail.com

doi : $10.3191 /$ thermalmed.32.13

(c) 2016 Japanese Society for Thermal Medicine 
Thermal Med, 32 [3] : 13-16, 2016.

施行. 開腹時の所見で腹水・腹膜播種は認められなかったものの, 胆囊癌の十二指腸・横行結腸への直 接浸潤が認められ切除不能と判断. Gemcitabine (GEM)/S1 による化学療法開始の予定であったが，本 人および家族の希望で 5 月上旬に当院を受診した.

現症：身長 $150 \mathrm{~cm}$ 体重 $52 \mathrm{~kg}$ PSO. 血液検査所見：血液生化学検査值, 軽度の貧血 (Hb11.6) 以外 に特記事項なし. 腫瘍マーカー值は CEA $2.5 \mathrm{ng} / \mathrm{ml}$ CA19-9 $12 \mathrm{U} / \mathrm{ml}$ と正常範囲内. 造影 CT 検查所 見：胆囊壁はびまん性に肥厚し増強効果を認める。胆囊床部の肝実質は若干の低吸収を呈している。十 二指腸下行脚周囲に直接浸潤を思わせる余分な軟部陰影あり (Fig. 1).

治療経過：周囲腸管への直接浸潤が認められるものの腫瘍の範囲が限局していたため，放射線治療と GEM による化学療法に温熱療法，高気圧酸素療法を併用して施行することとなった．200X 年 5 月よ り放射線治療を開始. 放射線治療は $10 \mathrm{MVX}$ 線で原体照射 +1 門照射で $1.8 \mathrm{~Gy} / 1 \mathrm{Fr}$ で $50.4 \mathrm{~Gy} / 28 \mathrm{Fr}$ ま で照射，その後原体照射のみで $1.8 \mathrm{~Gy} / 1 \mathrm{Fr}$ で 200X/6 月下旬まで計 $61.2 \mathrm{~Gy}$ の照射を行った. 放射線治療に併用して化学療法も開始した，化 学療法は 200X 年5 月ょり biweekly GEM $(\mathrm{GEM}=700 \mathrm{mg} /$ body) を施行, 放射線治療終 了後もそのまま治療継続し, $200 \mathrm{X}+1$ 年 5 月 までの 1 年間で計 13 クール施行した．その後 $\mathrm{S}-1 \quad 100 \mathrm{mg}$ を隔日投与で $200 \mathrm{X}+1$ 年 5 月 $\sim 200 \mathrm{X}+2$ 年 9 月まで 1 年 4 ヶ月内服継続し た. 温熱療法はサーモトロンRF-8を使用 (Fig. 2)，200X 年 5 月〜 7 月まで計 9 回施行 (7 回目までは 1 回/週で施行し，8，9回目は 1 回 $/ 2$ 週で施行) した.さらに高気圧酸素療法 も，化学療法の施行日にあわせて $200 X$ 年 5 月 〜 月まで計 6 回施行 (1 回/週) した. なお, これらの治療はすべて外来通院で施行した，放 射線治療終了時の computed tomography (CT)

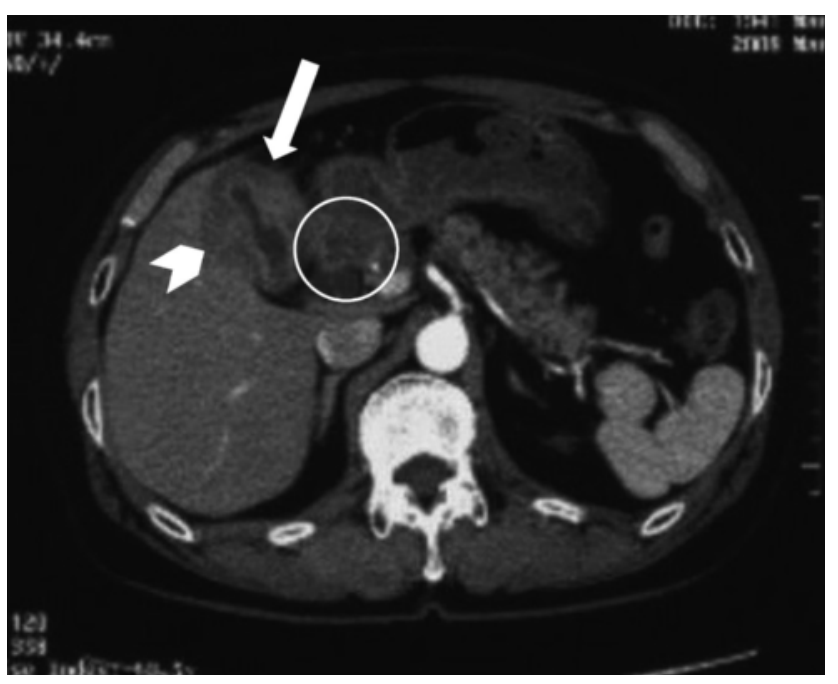

Fig. 1. Abdominal enhanced CT in May 9, 200X This image is a state before treatment and shows thickening of gallbladder wall (arrow), direct invasion to liver (arrowheads) and duodenum (white circle).
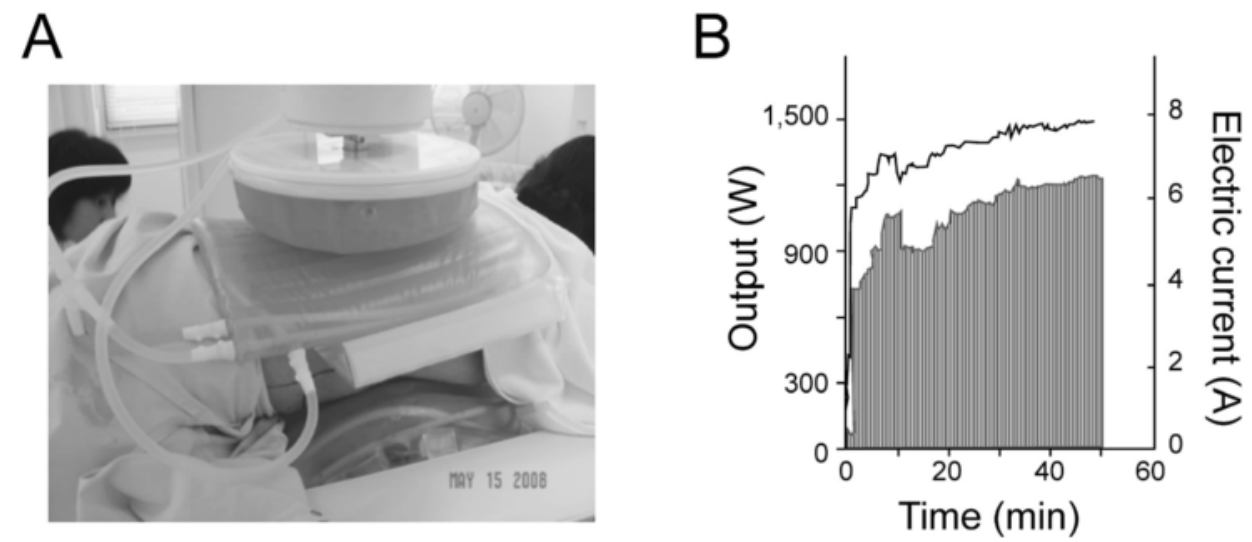

Fig. 2. The state of the hyperthermia using RF-8 (A) and warming graph (B) The closed column represents output, and the line represents electric current. 


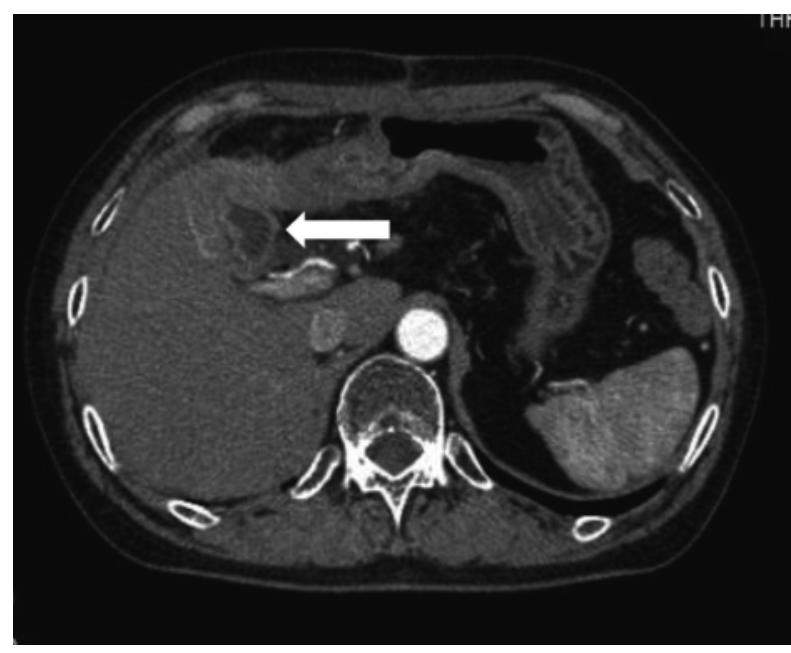

Fig. 3. Abdominal enhanced CT in July 10, 200X This image is a state just after radiotherapy and shows reduction of gallbladder wall thickening (arrows).

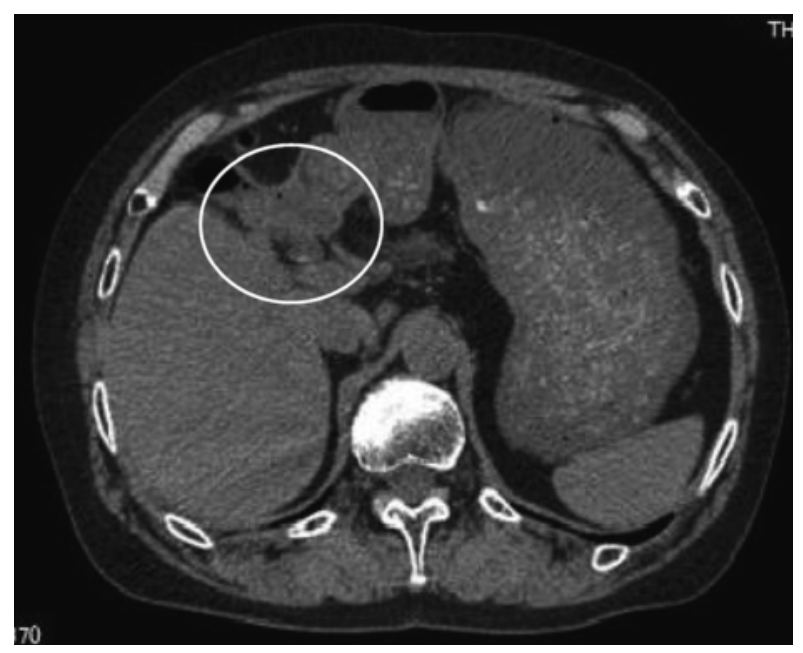

Fig. 4. Abdominal enhanced CT in June 2, 200X +3 This image is a state three years after the therapy and shows no evidence of recurrent tumor (white circle).

を Fig. 3 に示す. 胆囊壁の肥厚および周囲肝実質の低吸収域は経時的に縮小し，また十二指腸への浸 潤を示唆する軟部陰影の縮小が認められた. さらに温熱療法・高気圧酸素療法終了 1 年後の CT 画像で も病変の再発は認められず完全奏効を維持, 治療から 3 年後の CT (造影剂アレルギーあり単純 CT を 施行) でも完全奏効を維持していた (Fig. 4). 現在診断から約 6 年 9r月が経過しているが再発・転移は 認められず経過は良好である。

治療による有害事象：200X 年 10 月 (放射線治療終了 3r月後), 食後に胃が締まる感覚が出現し持続 するため, $200 X+1$ 年 1 月胃内視鏡検查施行したところ, 放射線治療による胃炎・十二指腸炎の疑いで あった. プロトンポンプ阻害薬および粘膜防御因子増強薬の内服を開始し, 症状は経時的に軽減した. $200 X+2$ 年 4 月の胃内視鏡再検では明らかな異常所見は指摘できなかった。 その他, 明らかな有害事 象の出現は認められていない.

\section{考察}

胆囊癌は外科的切除が唯一の根治治療であるが, 診断時点ですでに切除不能の進行癌であることが多 い. その理由として, 胆囊癌初期には症状に乏しいこと, 胆囊の解剖学的特異性から比較的早期に周囲 臟器 (肝臟, 十二指腸, 結腸等) に進展, また肝十二指腸間膜に浸潤が及ぶと豊富なリンパ管網や神経 叢を介して肝門部あるいは膵頭部方向に癌が進展すること等があげられる2).

肝内直接浸潤, 十二指腸, 結腸などの周囲㵴器浸潤例では, 拡大手術により治癒切除が得られる症例 もあるが，切除不能の局所進展因子について明らかなコンセンサスが得られていないのが現状である (胆道癌診療ガイドラインより) ${ }^{3}$. 本症例も, 開腹手術により十二指腸・横行結腸への直接浸潤が認めら れ切除不能と判断され外科的切除以外の治療を行わざるを得ない状況であった.

放射線治療群と無治療群との比較で, 放射線治療群の生存期間中央值（MST）は9ケ月と無治療群の 4ヶ月と比較して有意な延長を示すものの文，長期予後は期待できないのが現状である.

当院受診後, 放射線治療, 化学療法, 温熱療法, 高気圧酸素療法の集学的な治療が開始となっている が，これは画像上腫瘍の進展範囲が限局していると判断したこと，化学・放射線療法に温熱療法を加え 
Thermal Med, 32 [3] : 13-16, 2016.

ることでより高い治療効果が期待できると判断したこと5,6)，また放射線治療および化学療法の増感作 用としての高気圧酸素療法の有用性を期待したことがあげられる る $^{7,8)}$.

温熱療法は，抗癌剤による細胞障害からの回復を抑制するとともに，抗癌剤の細胞致死効果を増強す る．また，放射線と温熱に対する細胞周期の感受性が異なることから，放射線単独より温熱を併用する ことで制癌効果が増強する ${ }^{9,10)}$.

温熱・化学・放射線療法は比較的短期間に行う集学的局所制御療法であるが，本症例は周囲臟器への 直接浸潤が認められたにもかかわらず病変の肝十二指腸間膜への浸潤を抑えることができ, 良好な腫瘍 制御を得ることができたものと思われる.さらに，1 年間の GEM による化学療法， 1 年 4 ケ月の S- 1 を追加施行することで腫瘍の全身への広がりを抑えることができ，6 年以上の長期にわたる無病生存を 維持できたことが予想される.

胆道癌取り扱い規約 (第 5 版) に抢いて，このような進行胆囊癌に対する集学的な治療法は揭載され ていない，通常は全身化学療法や放射線治療が治療の主体となるが，本症例のように局所に病変が限局 していることが予想される症例については温熱療法を併用した集学的な治療が有用であるということが 示唆され，拡大手術の代替治療法となりうる可能性が示された。

\section{引用文献}

1）神澤輝実，屠聿揚，江川直人，石渡淳一，唐沢克之，佐及木常雄，鶴田耕二，岡本篤武，高橋俊雄：進行胆囊癌に 対する温熱・化学・放射線の三者併用療法. 胆道, $14: 354-360,2000$.

2）西村健志, 鈴木信親, 三浦泰朗, 片山原子, 平田勝, 田中潔：胆囊癌術後肝再発に対し，放射線治療と $\mathrm{S} 1$, シスプ ラチン併用化学療法により CR が得られた 1例. 日本臨床外科学会誌，70：170-173, 2009.

3）日本肝胆膵外科学会 胆道癌診療ガイドライン作成委員会編：エビデンスに基づいた胆道癌診療ガイドライン 改訂 第 2 版. 医学図書出版, 2014 .

4) Shinohara E.T., Mitra N., Guo M., Metz J.M.: Radiotherapy is associated with improved survival in adjuvant and palliative treatment of extrahepatic cholangiocarcinomas. Int J Radiat Oncol Biol Phys, 74: 1191-1198, 2009.

5）日本ハイパーサーミア学会効果判定基準作成委員会：ハイパーサーミアの治療効果判定基準 (案). 日本ハイパー サーミア誌，7: 482, 1997.

6）石渡淳一，田中良明：胆囊癌の集学的治療. 医学のあゆみ，168：1148-1152, 1994.

7) Kawasoe Y., Yokouchi M., Ueno Y., Iwaya H., Yoshida H., Komiya S. : Hyperbaric oxygen as a chemotherapy adjuvant in the treatment of osteosarcoma. Oncol Rep, 22: 1045-1050, 2009.

8) Ogawa K., Ishiuchi S., Inoue O., Yoshii Y., Saito A., Watanabe T., Iraha S., Toita T., Kakinohana Y., Ariga T., Kasuya G., Murayama S. : Phase II trial of radiotherapy after hyperbaric oxygenation with multiagent chemotherapy (Procarbazine, Nimustine, and Vincristine) for high grade-gliomas : logn term results. Int J Radiat Oncol Biol Phys, 82 : 732-738, 2012.

9) Jones E.L., Samulski T.V., Vujaskovic Z., Prosnitz L.R., Dewhirst M.W.: Hyperthemia as a Treatment Modality. "Principles and Practice of Radiation Oncology, $5^{\text {th }}$ ed." Eds. E.C. Halperin, C.A. Perez, L.W. Brady, Lippincott Williams \& Wilkins, pp.637-668, 2008.

10) Mohamed F., Marchettini P., Stuart O.A., Urano M., Sugarbaker P.H. : Thermal enhancement of new chemotherapeutic agents at moderate hyperthermia. Ann Surg Oncol, 10: 463-468, 2003. 